\title{
Thermal, spectroscopic and antimicrobial activity characterization of some norfloxacin complexes
}

\author{
Wilhan Donizete Gonçalves Nunes ${ }^{1}$ - André Luiz Carneiro Soares do Nascimento ${ }^{1}$ Aniele Moura ${ }^{1}$. \\ Caroline Gaglieri ${ }^{2} \cdot$ Gustavo Brunelli Vallim $^{3} \cdot$ Luiz Carlos Nascimento $^{3} \cdot$ Roni Antônio Mendes $^{4}$ • \\ Massao lonashiro ${ }^{1}$. Flávio Junior Caires ${ }^{1,2}$
}

Received: 22 September 2017 / Accepted: 16 January 2018/Published online: 7 February 2018

(C) Akadémiai Kiadó, Budapest, Hungary 2018, corrected publication February 2018

\begin{abstract}
Coordination compounds of transition metals with norfloxacin (Nor) have potential to improve its effectiveness, as already discussed for some compounds found in the literature. The complexes in the solid state were prepared by precipitation of the respective metal cation $(\mathrm{M}=\mathrm{Mn}(\mathrm{II}), \mathrm{Co}(\mathrm{II}), \mathrm{Ni}(\mathrm{II}), \mathrm{Cu}(\mathrm{II})$ and $\mathrm{Zn}(\mathrm{II})$ ) with a norfloxacin sodium salt solution. The thermal behavior under oxidative and pyrolysis conditions was investigated employing thermogravimetry and differential thermal analysis (TG/DTG-DTA) and evolved gas analysis (EGA/TG-FTIR), and the complexes were characterized by elemental analysis (EA), EDTA complexometric titration, infrared spectroscopy (FTIR) and X-ray powder diffraction (XRD). By these results, the minimum formula was established as $\left[\mathrm{M}(\mathrm{Nor})_{2}\left(\mathrm{H}_{2} \mathrm{O}\right)_{2}\right] \cdot n \mathrm{H}_{2} \mathrm{O}$, where $n=3(\mathrm{Ni}), 2.5(\mathrm{Mn} \mathrm{Co}$, $\mathrm{Zn})$, or $2(\mathrm{Cu})$. The evolved gases identified during thermal decomposition of $\mathrm{Ni}$ and $\mathrm{Cu}$ complexes were ethylene, $\mathrm{CO}_{2}$ and $\mathrm{CO}$ for $\mathrm{Ni} ; \mathrm{CO}_{2}$ and ethane for $\mathrm{Cu}$. Also, antimicrobial activity of the complexes was evaluated by in vitro susceptibility test using the agar diffusion method, and the results were compared with the uncomplexed molecule. It was found that norfloxacin complexation modifies its antibacterial activity. The activity depends on the type of metal ion and microorganism; $\mathrm{Mn}$ (II), $\mathrm{Co}(\mathrm{II})$ and $\mathrm{Zn}$ (II) complexes significantly increased activity against the tested gram-negative bacteria.
\end{abstract}

Keywords Norfloxacin · Complexes · Thermal behavior · Antibacterial activity

The original version of this article was revised: The fifth author's given name was misspelled as "Gabriel". The author name is corrected in the article.

Electronic supplementary material The online version of this article (https://doi.org/10.1007/s10973-018-7019-z) contains supplementary material, which is available to authorized users.

Flávio Junior Caires

caires.flavio@yahoo.com.br; caires.flavio@fc.unesp.br

Wilhan Donizete Gonçalves Nunes

wdgnsl@gmail.com

André Luiz Carneiro Soares do Nascimento

nascimento.a.1.c@gmail.com

Aniele Moura

m.aniele@yahoo.com.br

Caroline Gaglieri

carolinegaglieri@fc.unesp.br

Gustavo Brunelli Vallim

gustavobvallim@gmail.com

Luiz Carlos Nascimento

luiz.nascimento@unifal-mg.edu.br

\section{Introduction}

Quinolones is a term commonly used to designate quinolone carboxylic acids, which are a group of synthetic antibacterial agents containing an 1-ethyl-6-fluoro-1,4-

Roni Antônio Mendes

roni.mendes@unifal-mg.edu.br

Massao Ionashiro

massaoi@yahoo.com.br

1 Instituto de Química, Universidade Estadual Paulista (UNESP), Araraquara, SP, Brazil

2 Faculdade de Ciências, Universidade Estadual Paulista (UNESP), Bauru, SP, Brazil

3 Faculdade de Ciências Farmacêuticas, Universidade Federal de Alfenas (UNIFAL-MG), Alfenas, MG CEP 37130-001, Brazil

4 Instituto de Ciência e Tecnologia, Universidade Federal de Alfenas (UNIFAL-MG), Poços de Caldas, MG CEP 37715-400, Brazil 
dihydro-4-oxo-7-(1-piperazinyl)-3-quinolinecarboxylic acid [1]. Norfloxacin is a molecule pertaining to this group, most specifically to the group of fluoroquinolones. It is a wide-ranging drug used to treat bacterial infections of the urinary and respiratory tracts and the skin, among others. Figure 1 shows the structural formula of 1-ethyl-6-fluoro4-oxo-7-piperazin-1-ylquinoline-3-carboxylic acid also known as norfloxacin, one of the quinolones antibiotics that is most used in clinical treatments.

In general, norfloxacin has activity against a wide variety of aerobic Gram-negative and Gram-positive bacterial strains, but its activity against aminoglycoside-resistant Pseudomonas aeruginosa and $\beta$-lactamaseproducing organisms have been highlighted [2].The action of norfloxacin in these microorganisms involves inhibition of bacterial DNA gyrase that is essential for DNA replication [3]. DNA gyrase is an important enzyme present in bacterial chromosome replication, the reaction against gram-negative and gram-positive bacteria by norfloxacin results in the formation of a ternary complex between norfloxacin, the enzyme and bound DNA segment. A moiety of carbonyl and carboxyl from norfloxacin bind with DNA, causing the break of DNA-gyrase complex. This mechanism is responsible for the antibacterial activity of this fluoroquinolone as reported in the literature [4]. Fluorine (F) and the piperazine group give an extra stabilization to the ternary complex norfloxacin-enzyme-DNA because it interacts with the enzyme; this stabilization is responsible for the effectiveness potential antibacterial action. However, this compound presents poor aqueous solubility that causes a low oral bioavailability, generating a poor metabolization of norfloxacin [5, 6]. Garnayak and Patel [4] have reported that less than $10 \%$ of the drug containing norfloxacin as active principle is metabolized, part of the drug excreted by renal excretion and a fraction of the drug remained unaltered by the metabolism.

A literature survey reveals several works involving complexes of $\mathrm{Cu}(\mathrm{II}), \mathrm{Co}(\mathrm{II}), \mathrm{Ni}(\mathrm{II}), \mathrm{Zn}(\mathrm{II}), \mathrm{Mn}$ (II) and $\mathrm{Ru}(\mathrm{III})$ with norfloxacin that have shown increased<smiles>CCn1cc(C(=O)O)c(=O)c2cc(F)c(N3CCNCC3)cc21</smiles>

Fig. 1 Chemical structure of norfloxacin biological activity when compared to the uncomplexed norfloxacin [7-14].

Various drugs molecules can present modified pharmacological and toxicological properties when complexed with metal ions. The $\mathrm{Cu}^{2+}$ cation for example is one of the most widely employed in the studies of biological activity from complexed drugs since these complexes have been showing action against a wide variety of diseases such as gastric ulcers and tumors and also can present bactericidal and fungicidal action [15]. Norfloxacin is the most studied quinolone in the literature with several complexes reported. These studies deal mainly with the synthesis and crystal structure determination and show that quinolone compounds have capability to form polynuclear complexes. The capability of norfloxacin to coordinate with metal ions is due to the presence of the carbonyl oxygen and carboxylic acid groups in the molecule [10].

Since norfloxacin and its metal complexes have been of great interest in scientific research and, consequently, have a great potential for several applications, the main objective of this work was to investigate the thermal behavior of these compounds under oxidative and pyrolysis conditions. In this way, the complexes were synthesized and characterized by chemical analysis (EDTA complexometric titration), thermoanalytical (TG/DTG-DTA and DSC) and spectroscopic techniques (FTIR and XRD). In addition, the antibacterial activity of the complexes against various types of microorganisms was evaluated by in vitro susceptibility testing by the agar disk diffusion method.

\section{Experimental}

\section{Materials}

The norfloxacin $\left(\mathrm{C}_{16} \mathrm{H}_{18} \mathrm{FN}_{3} \mathrm{O}_{3}\right.$, HNor $)$ with purity greater than 98\% (analytical standard) was obtained from SigmaAldrich. All chemicals used for the preparation of the complexes were of analytical reagent grade, commercially available from different sources: $\mathrm{MnCl}_{2}, \mathrm{NiCl}_{2} \cdot 6 \mathrm{H}_{2} \mathrm{O}$, $\mathrm{CuSO}_{4} \cdot 5 \mathrm{H}_{2} \mathrm{O}$ (99.9\%, Merck), $\mathrm{CoCl}_{2} \cdot 6 \mathrm{H}_{2} \mathrm{O}$ (99.9\%, MALLINCKRODT) and $\mathrm{ZnCl}_{2}$ (99.9\%, CARLO ERBA).

\section{Synthesis}

Aqueous $0.1 \mathrm{~mol} \mathrm{~L}^{-1}$ solution of norfloxacin sodium salt was prepared by neutralizing an aqueous suspension of norfloxacin with sodium hydroxide $0.1 \mathrm{~mol} \mathrm{~L}^{-1}$ solution until $\mathrm{pH} 9.5$, heated up to near ebullition. During cooling of the solution, partial precipitation of the ligand was observed. Aqueous $0.1 \mathrm{~mol} \mathrm{~L}^{-1}$ solution of bivalent metal ions was prepared by dissolving the corresponding chlorides $(\mathrm{Mn}(\mathrm{II}), \mathrm{Co}(\mathrm{II}), \mathrm{Ni}(\mathrm{II}), \mathrm{Zn}(\mathrm{II}))$ or sulfate $(\mathrm{Cu}(\mathrm{II}))$. 
The solid-state compounds were obtained by adding slowly with continuous stirring $50.0 \mathrm{~mL}$ of the respective metal ions solutions to $100.0 \mathrm{~mL}$ of norfloxacin sodium salt solution, heated up to near ebullition. The system was cooled down to ambient temperature, and the precipitate was filtered off, washed with distilled water until chloride or sulfate ions were eliminated (qualitative test with $\mathrm{AgNO}_{3} / \mathrm{HNO}_{3}$ solution for chloride ions or $\mathrm{BaCl}_{2}$ solution for sulfate ones), dried at $50{ }^{\circ} \mathrm{C}$ in forced circulation air oven during $12 \mathrm{~h}$ and kept in a desiccator over anhydrous calcium chloride. All attempts to synthesize the iron(II) complex were unsuccessful.

\section{Characterization}

The carbon, hydrogen and nitrogen contents were determined by microanalytical procedures using a $\mathrm{CHNS} / \mathrm{O}$ Elemental Analyzer from PerkinElmer (model 2400 Series II CHNS/O) and also by calculations based on the mass losses of the TG curves.

In the solid-state metal ions, hydration water and ligand contents were determined from TG curves. The metal ions were also determined by complexometry with standard EDTA solution after igniting the compounds to the respective oxides and their dissolution in hydrochloric acid solution.

The X-ray powder patterns were obtained by using a Siemens D-500 X-ray diffractometer, employing $\mathrm{CuK} \alpha$ radiation $(\lambda=1.5456 \AA$ ) and setting of $40 \mathrm{kV}$ and $20 \mathrm{~mA}$. The interplanar distances were obtained using the Bragg's law.

The attenuate total reflectance infrared spectra for all samples were measured in a Nicolet's iS10 FTIR spectrophotometer, using an ATR accessory with Ge window.

Simultaneous TG-DTA and DSC curves were obtained with two thermal analysis system, model SDT 2960 and DSC Q10, respectively, both from TA Instruments. The furnace was purged with air or nitrogen, at a flow rate of $100 \mathrm{~mL} \mathrm{~min}^{-1}$ for TG-DTA and $50 \mathrm{~mL} \mathrm{~min}^{-1}$ for DSC experiments. A heating rate of $10{ }^{\circ} \mathrm{C} \mathrm{min}{ }^{-1}$ was adopted, with samples weighing about $7 \mathrm{mg}$ for TG-DTA and $3 \mathrm{mg}$ for DSC experiments. Alumina and aluminum crucibles, the latter with perforated lids, were used for recording the TG-DTA and DSC curves, respectively.

The evolved gas analysis (EGA/TG-DSC-FTIR) was performed by coupling a Mettler Toledo's TG/DSC1 simultaneous TG-DSC to the Nicolet's infrared spectrophotometer. The furnace outlet was coupled to the spectrophotometer through a heated transfer line $\left(225^{\circ} \mathrm{C}\right)$ to a heated gas cell $\left(250{ }^{\circ} \mathrm{C}\right)$. The spectra were collected at 16 scans per spectrum, $4 \mathrm{~cm}^{-1}$ resolution.
Antimicrobial activity was evaluated by the agar disk diffusion method against Staphylococcus aureus ATCC 6538, Escherichia coli ATCC 25922, Pseudomonas aeruginosa ATCC 27853, Listeria monocytogenes CDC 4544 and Candida albicans ATCC 10231. Initial solutions of the complexes and norfloxacin drug, with the concentration $1.0 \mathrm{mg} \mathrm{mL}^{-1}$, were prepared using chloroform as solvent. Blank filter disks with $5.0 \mathrm{~mm}$ diameter were impregnated with $10.0 \mu \mathrm{L}$ of the solutions of the compounds and maintained until complete evaporation of the solvent. A $100.0 \mu \mathrm{L}$ of $0.5 \mathrm{McF}$ arland bacterial suspension (c.a. $1.5 \times 10^{8}$ bacterial cells $\mathrm{mL}^{-1}$ ) was inoculated in Mueller-Hinton agar plate [Brand: Titan Biotech, India. Composition: beef infusion $(11.4 \mathrm{~g})$; casein acid hydrolysate (0.665 g); agar (0.646 g); starch (0.057 g); pH 7.3; distilled water (make up to $1 \mathrm{~L}$ )]. After the complete bacterial absorption ( $5 \mathrm{~min}$ at room temperature), the disks were placed on the inoculated Mueller-Hinton agar with a distance of $5 \mathrm{~cm}$ from each other. For the activity test against $C$. albicans, nystatin was used as positive control. The plates were incubated at $37^{\circ} \mathrm{C}$ in ambient air for 18-24 h. The inhibition zone diameters for all compounds were measured with a digital caliper. The experiment was carried out in triplicate.

\section{Results and discussion}

\section{Norfloxacin (HNor)}

The simultaneous TG-DTA and DSC curves of norfloxacin are shown in Fig. 2a, b.

These curves show total mass loss in four consecutive and/or overlapping steps between 60 and $720{ }^{\circ} \mathrm{C}$ and thermal events corresponding to these losses. The first mass loss between 65 and $105{ }^{\circ} \mathrm{C}$, corresponding to an indicium of endothermic event around $95^{\circ} \mathrm{C}$, is attributed to the dehydration with loss of $0.35 \mathrm{H}_{2} \mathrm{O}$ (adsorbed water).

The anhydrous compound is stable up to $260{ }^{\circ} \mathrm{C}$, and above this temperature, the mass loss occurs in three steps, between 260 and $355{ }^{\circ} \mathrm{C}, 355$ and $455{ }^{\circ} \mathrm{C}$ and 455 and $660{ }^{\circ} \mathrm{C}$, with loss of about $26.3,15.7$ and $58.1 \%$, respectively, corresponding to an endothermic peak at $450{ }^{\circ} \mathrm{C}$ (second step) attributed to the thermal decomposition and exothermic peaks at 320,345 and $570{ }^{\circ} \mathrm{C}$ (first and last steps) attributed to oxidation of the organic matter and/or the gaseous products evolved during the thermal decomposition.

The sharp endothermic peak at $221{ }^{\circ} \mathrm{C}$, without mass loss in the TG curve, is attributed to the melting of the compound. 


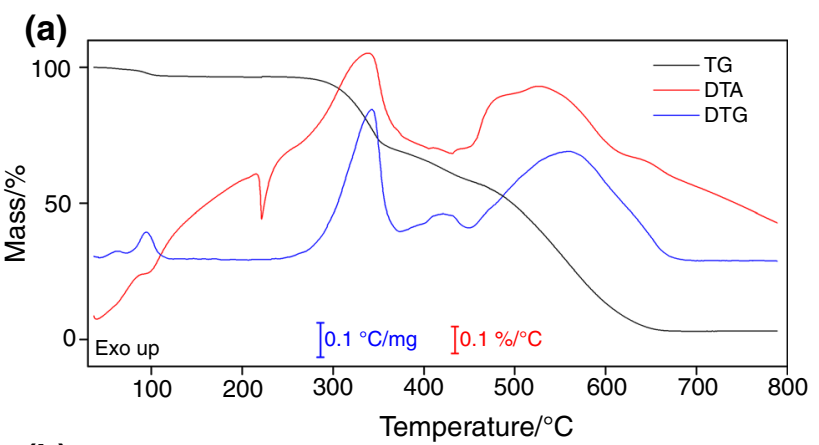

(b)

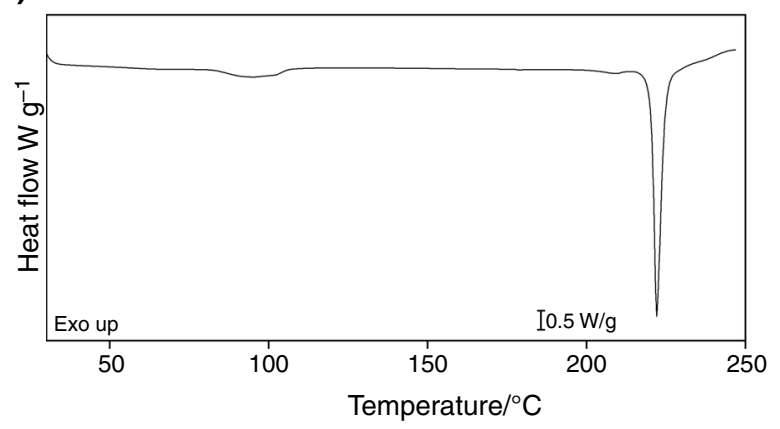

Fig. 2 a Simultaneous TG-DTA $(5.4667 \mathrm{mg})$ and b DSC curve $(2.1870 \mathrm{mg})$ of norfloxacin

\section{Norfloxacin complexes}

\section{Analytical results}

The analytical and thermoanalytical (TG) data are shown in Table 1.

These results are in excellent agreement, which shows that the complexes were synthesized with high purity, and so it was possible to establish the stoichiometry (minimum formula) for these compounds, which are in agreement with the general formula $\left[\mathrm{M}(\mathrm{Nor})_{2}\left(\mathrm{H}_{2} \mathrm{O}\right)_{2}\right] \cdot n \mathrm{H}_{2} \mathrm{O}$ where $\mathrm{M}=\mathrm{Mn}, \mathrm{Co}, \mathrm{Ni}, \mathrm{Cu}$ or $\mathrm{Zn}$; Nor is norfloxacin anion and $n=3(\mathrm{Ni}), 2.5(\mathrm{Mn} \mathrm{Co}, \mathrm{Zn})$ or $2(\mathrm{Cu})$. Even though just in $\mathrm{Mn}$ and $\mathrm{Cu}$ TG/DTG-DTA curves it was possible to identify two mass loss steps corresponding to dehydration process, this minimal formula was proposed based on the characteristic hexacoordinated nature of transition metals, and other studies found in the literature [16-18]. Table 1 also shows the elemental composition of the complexes determined by EA, supported by the calculations from the minimal formula determined by TG.

\section{TG/DTG-DTA}

The simultaneous TG/DTG-DTA of the compounds in dry air and nitrogen atmospheres are shown in Fig. 3.

The TG curves show that mass loss occurs in three, four or five consecutive and overlapping steps, depending on

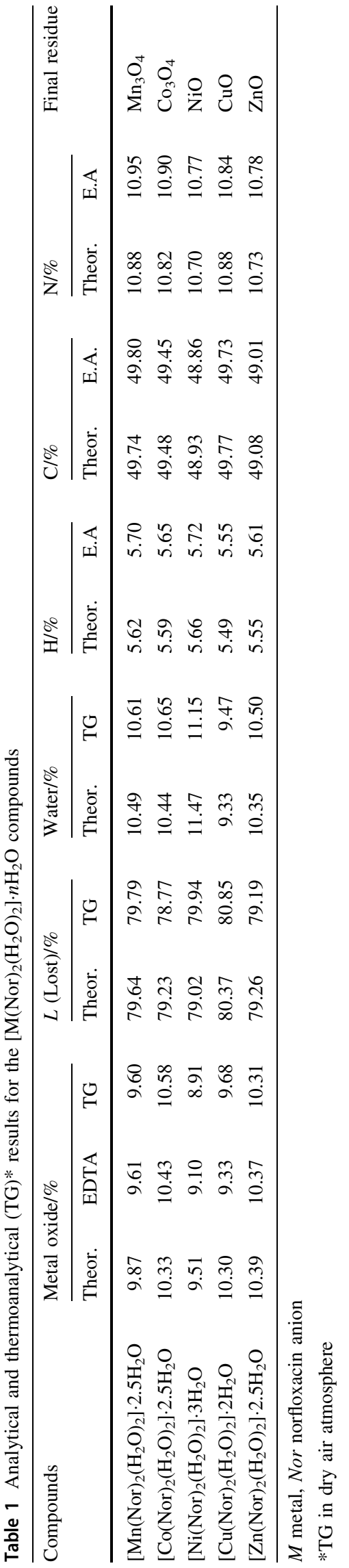




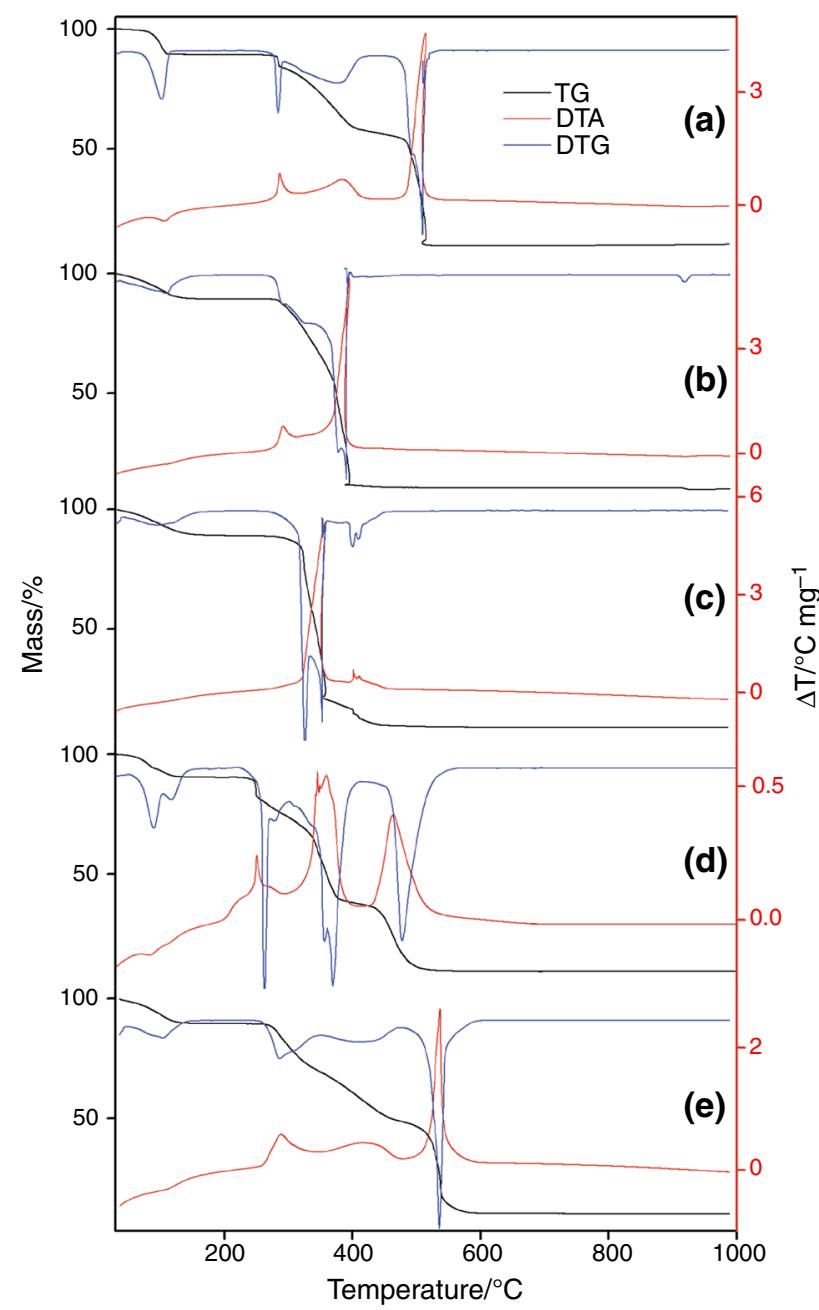

Fig. 3 Simultaneous TG-DTA curves of the synthesized compounds in dynamic dry air and $\mathrm{N}_{2}^{*}$ atmospheres: a, a* $\left[\mathrm{Mn}(\mathrm{Nor})_{2}\left(\mathrm{H}_{2} \mathrm{O}\right)_{2}\right.$ ]$2.5 \mathrm{H}_{2} \mathrm{O}(4.0131 \mathrm{mg}, 4.0630 \mathrm{mg} *) ; \mathrm{b}, \mathrm{b} *\left[\mathrm{Co}(\mathrm{Nor})_{2}\left(\mathrm{H}_{2} \mathrm{O}\right)_{2}\right] \cdot 2.5 \mathrm{H}_{2} \mathrm{O}$ (4.0472 mg, $4.0703 \mathrm{mg} *)$; c c* $\left[\mathrm{Ni}(\mathrm{Nor})_{2}\left(\mathrm{H}_{2} \mathrm{O}\right)_{2}\right] \cdot 3 \mathrm{H}_{2} \mathrm{O}(4.0085 \mathrm{mg}$,

the nature of the metal ions and the atmosphere used, corresponding to endothermic events in the DTA curve attributed to dehydration, thermal decomposition and reduction reactions and exothermic events attributed to oxidation of the organic matter and/or of the gaseous products released during the thermal decomposition.

These curves also show that the thermal stability of the anhydrous compounds as shown by TG/DTG-DTA curves depends on the nature of the metal ion, and they follow the order:

$\mathrm{Co}=\mathrm{Ni}>\mathrm{Mn}=\mathrm{Zn}>\mathrm{Cu}$ (air) $\mathrm{Ni}>\mathrm{Mn} \approx \mathrm{Co}>\mathrm{Zn}$ $>\mathrm{Cu}\left(\mathrm{N}_{2}\right)$

The mass losses $(\Delta m)$, temperature ranges $(\theta)$ and peak temperatures (Tp) observed for each step of the TG/DTGDTA curves are given in Table 2. As final residues, all compounds presented its respective bivalent oxide in air atmosphere. In nitrogen atmospheres, the final residues

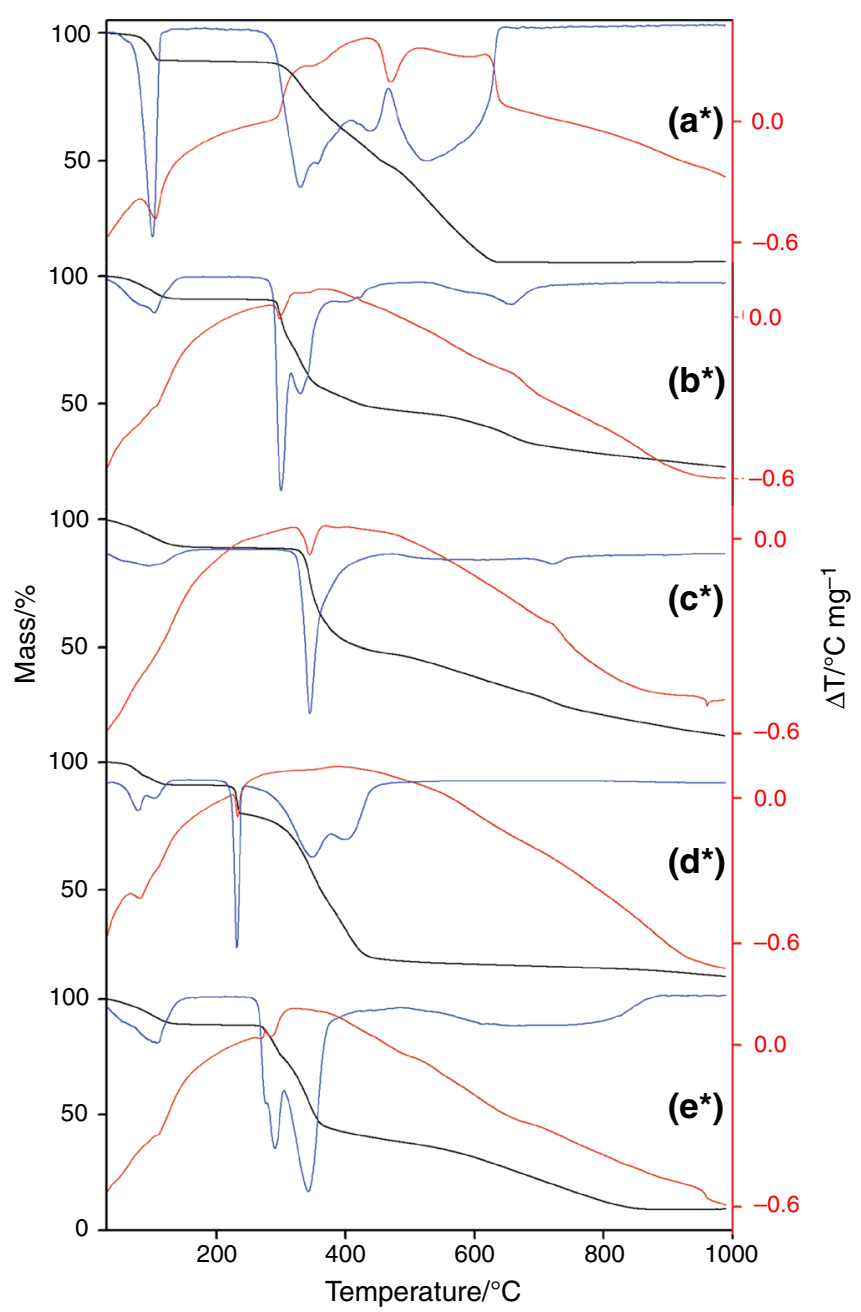

$4.0323 \mathrm{mg} *) ; \quad \mathrm{d}, \quad \mathrm{d}^{*} \quad\left[\mathrm{Cu}(\mathrm{Nor})_{2}\left(\mathrm{H}_{2} \mathrm{O}\right)_{2}\right] \cdot 2 \mathrm{H}_{2} \mathrm{O} \quad(4.0733 \mathrm{mg}$, $4.1282 \mathrm{mg} *) ; \quad$ e, e* $\quad\left[\mathrm{Zn}(\mathrm{Nor})_{2}\left(\mathrm{H}_{2} \mathrm{O}\right)_{2}\right] \cdot 2.5 \mathrm{H}_{2} \mathrm{O} \quad(4.0449 \mathrm{mg}$,

$4.1618 \mathrm{~m} *)$

were obtained as a mixture of carbonaceous residue and the bivalent metal oxide, a behavior already described for similar compounds under the same conditions of thermal analysis [19].

As the thermal behavior of the compound is dependent on the nature of the metal ions and the atmosphere used, the features of each of these compounds are discussed individually.

Manganese compound The simultaneous TG/DTG-DTA curves in air and nitrogen atmospheres are shown in Fig. 3a and $3 \mathrm{a}^{*}$, respectively. The first mass loss between 50 and $115^{\circ} \mathrm{C}$, corresponding to an endothermic peak at $107^{\circ} \mathrm{C}$ (air) or $105{ }^{\circ} \mathrm{C}\left(\mathrm{N}_{2}\right)$, is attributed to dehydration with loss of $4.5 \mathrm{H}_{2} \mathrm{O}$ (Calcd. $=10.49 \%$, TG (air) $=10.61 \%$, TG $\left.\left(\mathrm{N}_{2}\right)=11.09 \%\right)$. DTG curves show that dehydration occurs through a single and fast process with maximum 


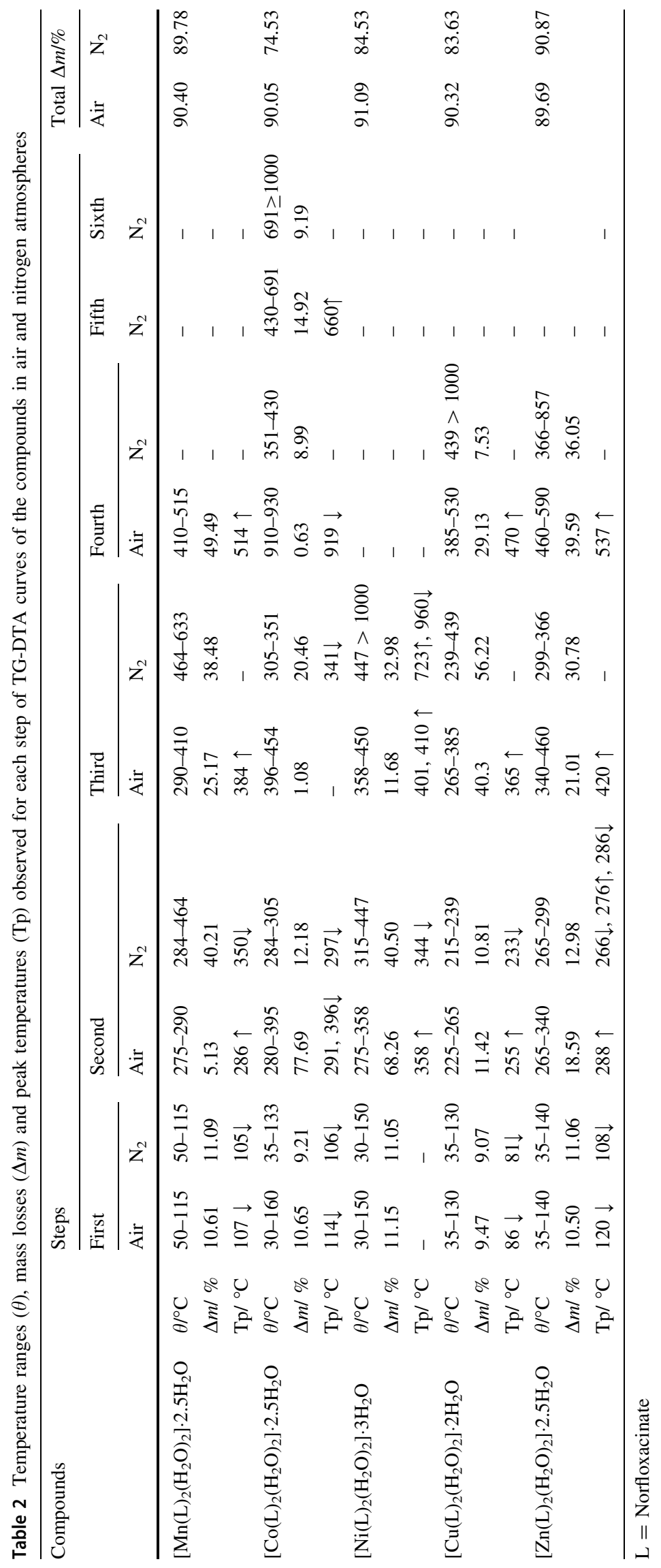


mass loss rate at $102{ }^{\circ} \mathrm{C}$ (air and $\mathrm{N}_{2}$ ), suggesting that all the water molecules present in the compound are bound in a similar way in the solid state although other studies report two coordinated water molecules $[17,18]$. The absence of two dehydration steps could be related to sample granulometry and preparation. TG/DTG-DTA curves also show that the anhydrous compound is thermally stable up to $275{ }^{\circ} \mathrm{C}$ (air) and $284{ }^{\circ} \mathrm{C}\left(\mathrm{N}_{2}\right)$, showing that as expected, in oxidative atmosphere (air) the compound is less stable than in inert $\left(\mathrm{N}_{2}\right)$ atmosphere.

In air atmosphere, the thermal decomposition occurs in three consecutive steps associated with an exothermic peak, attributed to oxidation of organic matter and/or of the gaseous products evolved during the thermal decomposition. The TG/DTG curve shows that the first and last steps are fast processes, while the second step is slower. Probably the last step is related to combustion of the carbonized material. The total mass loss up to $515^{\circ} \mathrm{C}$ is in agreement with the formation of $\mathrm{Mn}_{3} \mathrm{O}_{4}$ as final residue (Calcd. $=90.13 \%, \mathrm{TG}=90.40 \%)$, and in agreement with the literature [20].

In nitrogen atmosphere, the anhydrous compound undergoes thermal decomposition in two consecutive and overlapping steps, corresponding to endothermic events in the DTA curve. The DTG curves reveal that the thermal decomposition of the compound occurs through a very complex process, since several overlapping peaks are observed. As in air atmosphere, the total mass loss up to $633{ }^{\circ} \mathrm{C}$ is in agreement with the formation of $\mathrm{Mn}_{3} \mathrm{O}_{4}$ (Calcd. $=90.13 \%, \mathrm{TG}=89.78 \%$ ), which was confirmed by XRD.

Cobalt compound The simultaneous TG/DTG-DTA curves in air and $\mathrm{N}_{2}$ atmospheres are shown in Fig. 3b, b*, respectively. The first mass loss, corresponding to an endothermic peak at $114^{\circ} \mathrm{C}$ (air) or $106{ }^{\circ} \mathrm{C}\left(\mathrm{N}_{2}\right)$, is attributed to dehydration with loss of $4.5 \quad \mathrm{H}_{2} \mathrm{O}$ (Calcd. $=10.44 \%, \quad$ TG $\quad($ air $)=10.65 \%, \quad$ TG $\left.\left(\mathrm{N}_{2}\right)=9.21 \%\right)$.

The anhydrous compound is stable up to $280{ }^{\circ} \mathrm{C}$ (air) or $284{ }^{\circ} \mathrm{C}\left(\mathrm{N}_{2}\right)$, showing little influence of the atmosphere on thermal stability. On the other hand, the thermal decomposition steps of the anhydrous compound are strongly influenced by the atmosphere used.

In air atmosphere, the TG/DTG curve show that the thermal decomposition occurs in two steps, corresponding to two exothermic events in the DTA curve, attributed to the oxidation of the organic matter and/or the released gaseous products. The DTG curve shows three peaks, the first two related to slower processes, attributed to the beginning of the thermal decomposition of the compound and the last one due to a fast process, associated with a sharp exothermic peak in DTA curve, attributed to the combustion of the carbonized material. The total mass loss up to $515{ }^{\circ} \mathrm{C}$ is in agreement with the formation of $\mathrm{Co}_{3} \mathrm{O}_{4}$, as final residue $($ Calcd. $=89.67 \%, \mathrm{TG}=89.42 \%)$, which was confirmed by XRD. The last mass loss $(0.63 \%)$ between 910 and $930{ }^{\circ} \mathrm{C}$, corresponding to a small endothermic peak at $920^{\circ} \mathrm{C}$, is attributed to reduction reaction of $\mathrm{Co}_{3} \mathrm{O}_{4}$ to $\mathrm{CoO} \quad$ (Calcd. $=90.35 \%$, $\mathrm{TG}=90.05 \%$ ), and in agreement with the literature [21].

In nitrogen atmosphere, the TG/DTG curves of the anhydrous compound show at least five steps of mass loss, the first three attributed to the thermal decomposition of the compound, associated with small endothermic events in the DTA curve, and the last two, corresponding to a small exothermic event in the DTA curve, attributed to the pyrolysis of the carbonized material. The residue is a mixture of carbon and $\mathrm{CoO}$, as already observed for similar compounds in another study [19].

Nickel compound The simultaneous TG/DTG-DTA curves in air and $\mathrm{N}_{2}$ atmospheres are shown in Fig. 3c, $\mathrm{c}^{*}$, respectively. The first mass loss between 30 and $150{ }^{\circ} \mathrm{C}$, without thermal event in the DTA curves, is attributed to dehydration with loss of $5 \mathrm{H}_{2} \mathrm{O}$ (Calcd. $=11.47 \%$, $\mathrm{TG}$ (air) $=11.15 \%$, TG $\left.\left(\mathrm{N}_{2}\right)=11.05 \%\right)$.

In air atmosphere, the TG/DTG-DTA curves show that the anhydrous compound is stable up to $275^{\circ} \mathrm{C}$ and above this temperature the thermal decomposition also occurs in at least three steps, corresponding to exothermic peaks at 358,401 and $410{ }^{\circ} \mathrm{C}$ in the DTA curve. The first step is attributed to oxidation of the organic ligand and/or of the gaseous products evolved during the thermal decomposition, and the second is attributed to the oxidation of the carbonized material formed in the previous step. The discontinuity observed in the TG curve between 350 and $450{ }^{\circ} \mathrm{C}$, undoubtedly, is due to oxidation of the organic matter that occurs with combustion. The total mass loss up to $450{ }^{\circ} \mathrm{C}$ is in agreement with the formation of $\mathrm{NiO}$, as final residue $($ Calcd. $=90.49 \%, \quad \mathrm{TG}=91.09 \%$ ), which was confirmed by XRD.

In nitrogen atmosphere, a different thermal behavior is observed. The curves show that the thermal stability of anhydrous compound is increased up to $315^{\circ} \mathrm{C}$, when compared to air atmosphere. Above this temperature, the thermal decomposition occurs in at least two consecutive and/or overlapping steps, being the first associated with an endothermic event in DTA curve, which was attributed to thermal decomposition of the organic matter from the ligand. The second step was attributed to partial pyrolysis of the carbonized material formed in the previous step.

Copper compound The simultaneous TG/DTG-DTA curves in air and nitrogen atmosphere are shown in Fig. 3d, $\mathrm{d}^{*}$, respectively. The first mass loss between 35 and 
$130{ }^{\circ} \mathrm{C}$, corresponding to an endothermic peak at $86{ }^{\circ} \mathrm{C}$ (air) or $81{ }^{\circ} \mathrm{C}\left(\mathrm{N}_{2}\right)$ in the DTA curves, is attributed to dehydration with loss of $4 \mathrm{H}_{2} \mathrm{O}$ (Calcd. $=9.33 \%$, $\mathrm{TG}$ (air) $=9.47 \%$, TG $\left(\mathrm{N}_{2}\right)=9.07 \%$. In addition, these curves show that dehydration occurs in two overlapping steps, suggesting that the water molecules may be interacting in different ways in the crystalline structure of the compound. This agrees with previous studies, where two types of water molecules are present in this compound [16], suggesting that two $\mathrm{H}_{2} \mathrm{O}$ are directly coordinated to the metal center with coordination number 6 , and the other two weakly interacting with the compound.

The anhydrous compound is stable up to $225^{\circ} \mathrm{C}$ (air) and $215{ }^{\circ} \mathrm{C}\left(\mathrm{N}_{2}\right)$, and this discrepancy can be attributed to the higher thermal conductivity of the nitrogen gas and/or the presence of $\mathrm{CO}_{2}$ in the air atmosphere, and above this temperature, the thermal decomposition occurs in at least three consecutive and overlapping steps, for both atmospheres.

In air atmosphere, the steps of mass loss in the TG curve, corresponding to three exothermic peaks in the DTA curve, are attributed to oxidation of the organic matter and/ or of the gaseous products evolved during the thermal decomposition. The total mass loss up to $530{ }^{\circ} \mathrm{C}$ is in agreement with the formation of $\mathrm{CuO}$, as final residue (Calcd. $=89.70 \%, \mathrm{TG}=90.32 \%$ ), which was confirmed by XRD.

Under nitrogen atmosphere, once dehydrated, the compound undergoes thermal decomposition, which occurs in three consecutive and overlapping steps. The first and small step of mass loss observed in the TG curve, and associated to an endothermic event in the DTA curve, is attributed to the beginning of the thermal decomposition of the compound. The second mass loss step does not produce a thermal event in the DTA curve and is attributed to pyrolysis of the remaining compound. Finally, the last and slow step of mass loss is attributed to the pyrolysis of the carbonized matter formed in the previous stages.

Zinc compound The simultaneous TG/DTG-DTA curves in air and nitrogen atmospheres are shown in Fig. $3 \mathrm{e}, \mathrm{e}^{*}$, respectively. The first mass loss between 35 and $140{ }^{\circ} \mathrm{C}$, corresponding to endothermic peak at $120{ }^{\circ} \mathrm{C}$ (air) and $108{ }^{\circ} \mathrm{C}\left(\mathrm{N}_{2}\right)$, is attributed to dehydration with loss of 4.5 $\mathrm{H}_{2} \mathrm{O} \quad$ (Calcd. $=10.35 \%, \quad \mathrm{TG} \quad($ air $)=10.50 \%, \quad \mathrm{TG}$ $\left.\left(\mathrm{N}_{2}\right)=11.06 \%\right)$.

In both atmospheres, the anhydrous compound is stable up to $265^{\circ} \mathrm{C}$ and above this temperature the thermal decomposition occurs in three consecutive steps. In air atmosphere, the exothermic peaks in the DTA curve are attributed to oxidation of the organic matter and/or of the gaseous products evolved during the thermal decomposition. Under nitrogen atmosphere, the endothermic peak is attributed to thermal decomposition of the compound.

The total mass loss in both atmospheres is in agreement with the formation of $\mathrm{ZnO}$ as final residue (Calcd. $=89.61 \%$, TG (air) $=89.69 \%$, TG $\left(\mathrm{N}_{2}\right)=90.87 \%$ ) which was confirmed by XRD.

\section{Evolved gas analysis (EGA)}

The main gases evolved during thermal decomposition of the complexes in $\mathrm{N}_{2}$ atmosphere were identified. The $\left[\mathrm{Ni}(\mathrm{Nor})_{2}\left(\mathrm{H}_{2} \mathrm{O}\right)_{2}\right] \cdot 3 \mathrm{H}_{2} \mathrm{O}$ and $\left[\mathrm{Cu}(\mathrm{Nor})_{2}\left(\mathrm{H}_{2} \mathrm{O}\right)_{2}\right] \cdot 2 \mathrm{H}_{2} \mathrm{O}$ complexes were selected as representative for the series.

For Ni compound, the spectrum collected at 32 min of analysis indicates the formation of $\mathrm{CO}_{2}$ and ethylene gases, as can be seen in Fig. 4 by the comparison with reference spectra for these gases [22]. The formation of these gaseous species is associated with the second mass loss step observed in the TG curve. Also, CO is evolved at 52 and $60 \mathrm{~min}$ of analysis and is related with the third and fourth mass loss steps. At higher temperatures ( $97 \mathrm{~min}), \mathrm{CO}$ and $\mathrm{CO}_{2}$ gases are evolved, which indicates the partial oxidation of remaining carbonaceous residue.

For $\mathrm{Cu}$ compound, the evolved gases identified were $\mathrm{CO}_{2}$ at $20 \mathrm{~min}$, and ethane from 36 to $42 \mathrm{~min}$ of analysis. The formation of these gaseous products is associated with the second $\left(\mathrm{CO}_{2}\right)$, third and fourth (ethane) mass losses

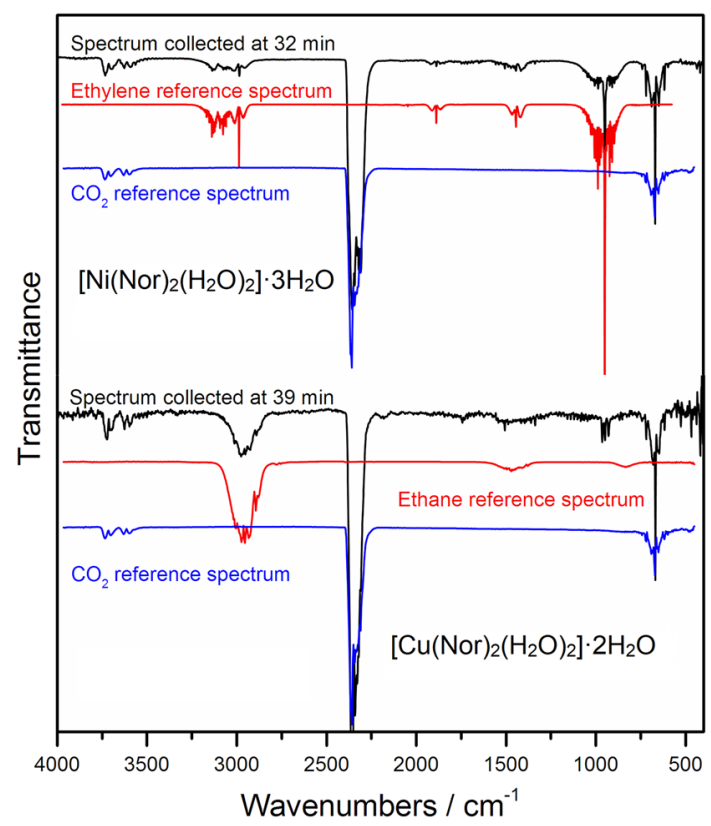

Fig. 4 Evolved gases infrared spectra collected for $\left[\mathrm{Ni}(\mathrm{Nor})_{2}\left(\mathrm{H}_{2}\right.\right.$ $\left.\mathrm{O})_{2}\right] \cdot 3 \mathrm{H}_{2} \mathrm{O}$ and $\left[\mathrm{Cu}(\mathrm{Nor})_{2}\left(\mathrm{H}_{2} \mathrm{O}\right)_{2}\right] \cdot 2 \mathrm{H}_{2} \mathrm{O}$ compounds in $\mathrm{N}_{2}$ atmosphere at different times of analysis 
observed in the TG curve, respectively. As in the case of $\mathrm{Ni}$ compound, the release of $\mathrm{CO}_{2}$ is continuous until the end of the analysis, indicating the slow oxidation of carbonaceous residue. In both compounds, during analysis it was not possible to differentiate atmospheric water vapor from that due to the first mass loss, since a very low amount is released.

\section{XRD}

All diffractograms are shown in Fig. 4. The peak positions and interplanar distances obtained from HNor diffractogram (Fig. 4a) are in agreement with the Ref [23], and it is also noted that the crystallinity increased in metal complexes, following the order $\mathrm{Cu}<\mathrm{Mn}<\mathrm{Ni}<\mathrm{Co}<$ $\mathrm{Zn}$.

The diffractograms of metal complexes with Co (Fig. 5c), Ni (Fig. 5d) and Zn (Fig. 5f), showed very similar peaks position, including the $100 \%$ peak and consequently values of interplanar distances: $2 \theta \quad 9.82^{\circ}$ $\left(\begin{array}{ll}d=9.0066 & \AA\end{array}\right) ; \quad 9.94^{\circ} \quad(d=8.9022 \quad \AA) \quad$ and $9.76^{\circ}$ $(d=9.0588 \AA)$, suggesting that these three metal complexes may have crystallized in the same structure. However, a deeper crystallographic study is necessary in order to obtain information about the crystalline structure.

The Mn (Fig. 5b) and Zn (Fig. 5e, f) diffractograms showed less crystallinity, so it is difficult to compare the peaks intensity between the diffractograms. Table S1 (supplementary material) summarizes the peaks positions, relative intensity and interplanar distances calculated for all compounds in order to facilitate the comparison between them.

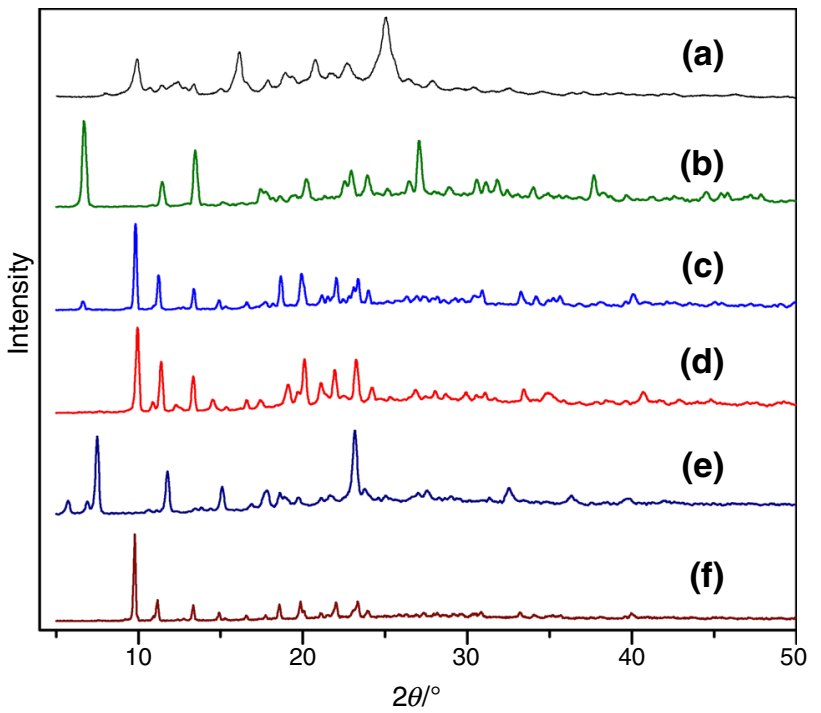

Fig. 5 X-ray powder diffractograms for a HNor, b $\left[\mathrm{Mn}(\mathrm{Nor})_{2}\left(\mathrm{H}_{2-}\right.\right.$ $\left.\mathrm{O})_{2}\right] \cdot 2.5 \mathrm{H}_{2} \mathrm{O}, \mathbf{c}\left[\mathrm{Co}(\mathrm{Nor})_{2}\left(\mathrm{H}_{2} \mathrm{O}\right)_{2}\right] 2.5 \mathrm{H}_{2} \mathrm{O}, \mathbf{d}\left[\mathrm{Ni}(\mathrm{Nor})_{2}\left(\mathrm{H}_{2} \mathrm{O}\right)_{2}\right] \cdot 3 \mathrm{H}_{2} \mathrm{O}$, e $\left[\mathrm{Cu}(\mathrm{Nor})_{2}\left(\mathrm{H}_{2} \mathrm{O}\right)_{2}\right] \cdot 2 \mathrm{H}_{2} \mathrm{O}$, f $\left[\mathrm{Zn}(\mathrm{Nor})_{2}\left(\mathrm{H}_{2} \mathrm{O}\right)_{2}\right] \cdot 2.5 \mathrm{H}_{2} \mathrm{O}$

\section{FTIR}

The infrared vibrational spectra of HNor, NaNor and metallic complexes are presented in Fig. 6, and the attributions for each band are summarized in Table 3

The broad, medium-intensity bands around $3400 \mathrm{~cm}^{-1}$ are attributed to the $\mathrm{O}-\mathrm{H}$ bond stretching $(\nu \mathrm{O}-\mathrm{H})$ of water molecules present in the compounds. Another interesting aspect that can be seen in these spectra is the absence of broad bands in the region of $2500 \mathrm{~cm}^{-1}$ [24], characteristic of the quaternized nitrogen of the piperazinyl group vibration, which means that the zwitterionic form of HNor is not involved in the coordination with the investigated metallic cations. So, only the anionic form of the ligand is present in the solid state, differently from the previously

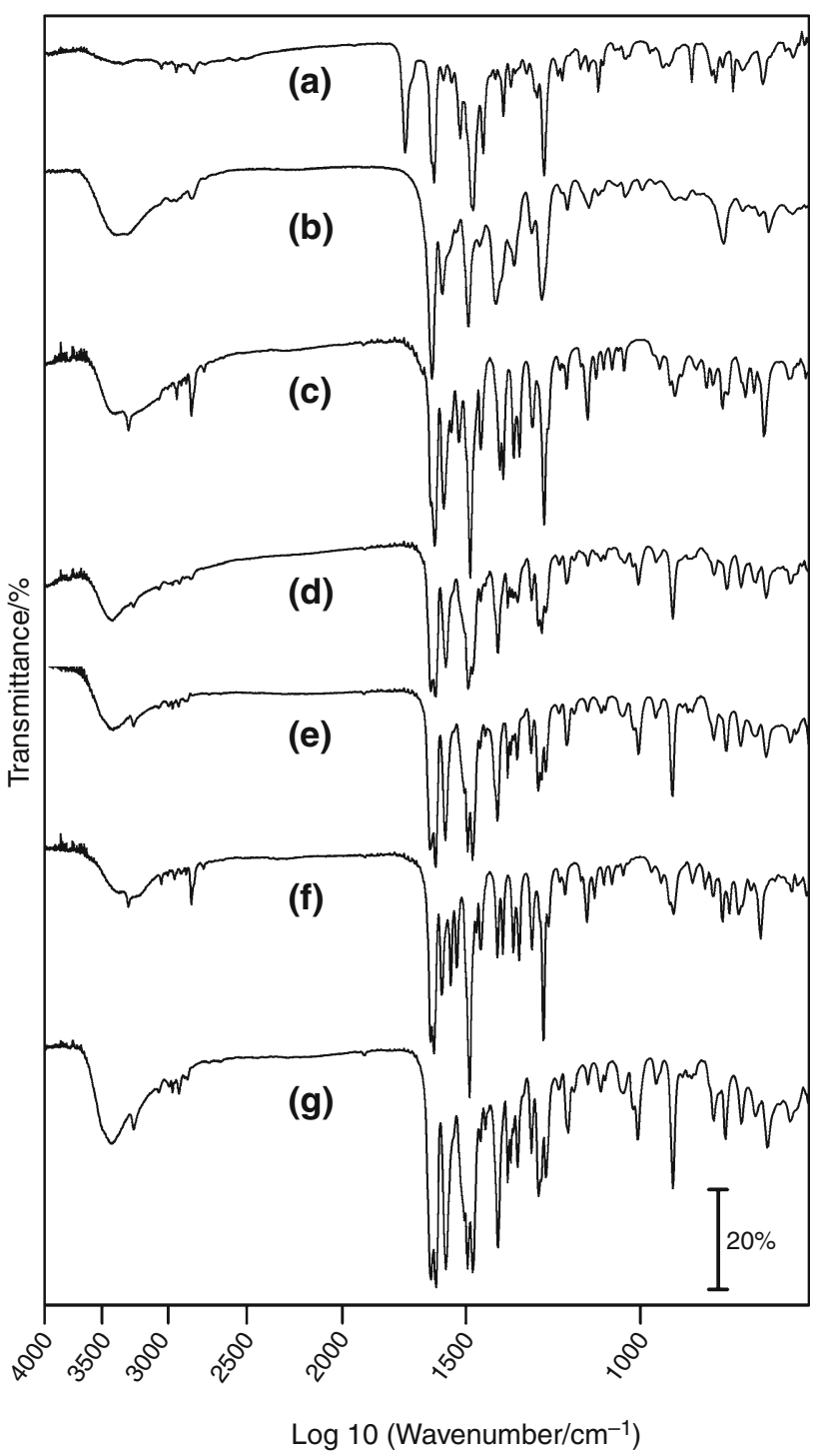

Fig. 6 FTIR spectra of aHNor, b NaNor, c $\left[\mathrm{Mn}(\mathrm{Nor})_{2}\left(\mathrm{H}_{2} \mathrm{O}\right)_{2}\right] \cdot 2.5 \mathrm{H}_{2}$ $\mathrm{O}, \quad$ d $\left[\mathrm{Co}(\mathrm{Nor})_{2}\left(\mathrm{H}_{2} \mathrm{O}\right)_{2}\right] \cdot 2.5 \mathrm{H}_{2} \mathrm{O}$, e $\left[\mathrm{Ni}(\mathrm{Nor})_{2}\left(\mathrm{H}_{2} \mathrm{O}\right)_{2}\right] \cdot 3 \mathrm{H}_{2} \mathrm{O}$, f $\left[\mathrm{Cu}(\mathrm{Nor})_{2}\left(\mathrm{H}_{2} \mathrm{O}\right)_{2}\right] \cdot 2 \mathrm{H}_{2} \mathrm{O}$ and $\mathbf{g}\left[\mathrm{Zn}(\mathrm{Nor})_{2}\left(\mathrm{H}_{2} \mathrm{O}\right)_{2}\right] \cdot 2.5 \mathrm{H}_{2} \mathrm{O}$ 


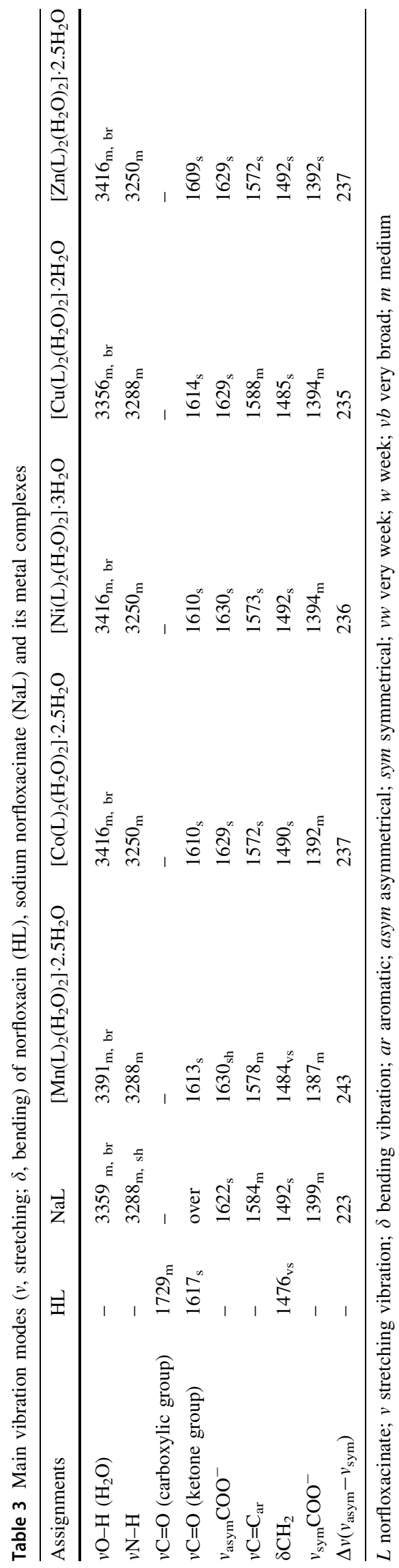

observed for other norfloxacin complexes [11, 25-27]. As can be seen, the band in $1729 \mathrm{~cm}^{-1}$ in the spectrum of HNor, which is attributed to the carbonyl stretching $(v \mathrm{C}=\mathrm{O})$ of the carboxylic group, is not present in the spectra of the complexes, confirming the total deprotonation and the absence of acid contamination in the sodium salt and in the complexes, in agreement with the thermoanalytical data. After complexation reaction, two new bands appear in the spectra of the complexes. The first is a strong intensity band around $1630 \mathrm{~cm}^{-1}$, and the second a medium-intensity band around $1390 \mathrm{~cm}^{-1}$, that are attributed to the asymmetric $\left(v_{\text {asym }} \mathrm{COO}^{-}\right)$and symmetric $\left(v_{\text {sym }} \mathrm{COO}^{-}\right)$stretching vibrations for the carboxylate group, respectively. These bands are useful in determining the coordination mode of the carboxylate group to the metal centers, based on a comparative study performed by Deacon and Phillips [28]. This strategy is based on the comparison of the separation of this two bands $(\Delta v)$ observed for the complexes with the value observed for the ionic ligand (its sodium salt). As can be seen in Table 3, the values of $\Delta v$ observed for the complexes are greater than the observed for the sodium salt, suggesting that the carboxylate coordinates in the monodentate mode. The strong band in the HNor spectrum with a peak at $1617 \mathrm{~cm}^{-1}$ is attributed to stretching vibration of carbonyl $(v \mathrm{C}=\mathrm{O}$ ) from ketonic group. This band is shifted to lower frequencies in the spectra of the complexes, suggesting that this group also participates in coordination. In this way, the spectroscopic results suggest that the ligand coordinates to the metal centers by one oxygen atom from the carboxylate and one from carbonyl of ketone group, resulting in a sixmembered ring chelate, in agreement with several works found in the literature $[9,13,17,29]$.

\section{Antimicrobial activity}

Testing for antibacterial activity against the microorganisms of prepared complexes and norfloxacin drug showed the presence of inhibition zones of bacterial growth around the impregnated paper disks in the vast majority of the plates. The results were submitted to analysis of variance (ANOVA) by applying the Scott-Knott test, with level of significance of 0.05 . The mean inhibition zones for each compound, and the interactions between their antibacterial activities are shown in Table 4.

By analyzing the data in Table 4, it is possible to suggest that:

1. The complexation did not significantly modify the activity of norfloxacin against the tested gram-positive bacteria (except complexation with copper, which caused loss of activity against $L$. monocytogenes); 
Table 4 Results of antimicrobial activity by the agar disk diffusion method

\begin{tabular}{llllll}
\hline Compounds & \multicolumn{2}{l}{ Zones of inhibition (mean in mm) } \\
\cline { 2 - 6 } & $\begin{array}{l}\text { S. aureus } \\
\text { (Gram }+ \text { cocci) }\end{array}$ & $\begin{array}{l}\text { E. coli } \\
\text { (Gram - bacilli) }\end{array}$ & $\begin{array}{l}\text { P. aeruginosa } \\
(\text { Gram - bacilli) }\end{array}$ & $\begin{array}{l}\text { L. monocytogenes } \\
\text { (Gram + bacilli) }\end{array}$ & $\begin{array}{c}\text { C. albicans } \\
\text { (yeast) }\end{array}$ \\
\hline $\mathrm{HNor}$ & $19.56^{\mathrm{a}}$ & $21.97^{\mathrm{a}}$ & $18.53^{\mathrm{a}}$ & $11.97^{\mathrm{a}}$ & 0 \\
{$\left[\mathrm{Mn}(\mathrm{Nor})_{2}\left(\mathrm{H}_{2} \mathrm{O}\right)_{2}\right] \cdot 2.5 \mathrm{H}_{2} \mathrm{O}$} & $25.21^{\mathrm{a}}$ & $27.97^{\mathrm{b}}$ & $26.83^{\mathrm{b}}$ & $10.83^{\mathrm{a}}$ & 0 \\
{$\left[\mathrm{Co}(\mathrm{Nor})_{2}\left(\mathrm{H}_{2} \mathrm{O}\right)_{2}\right] \cdot 2.5 \mathrm{H}_{2} \mathrm{O}$} & $23.01^{\mathrm{a}}$ & $26.90^{\mathrm{b}}$ & $25.20^{\mathrm{b}}$ & $13.51^{\mathrm{a}}$ & 0 \\
{$\left[\mathrm{Ni}(\mathrm{Nor})_{2}\left(\mathrm{H}_{2} \mathrm{O}\right)_{2}\right] \cdot 3 \mathrm{H}_{2} \mathrm{O}$} & $21.37^{\mathrm{a}}$ & $23.13^{\mathrm{a}}$ & $21.47^{\mathrm{a}}$ & $6.76^{\mathrm{a}}$ & 0 \\
{$\left[\mathrm{Cu}(\mathrm{Nor})_{2}\left(\mathrm{H}_{2} \mathrm{O}\right)_{2}\right] \cdot 2 \mathrm{H}_{2} \mathrm{O}$} & $21.27^{\mathrm{a}}$ & $25.73^{\mathrm{b}}$ & $17.66^{\mathrm{a}}$ & 0 & 0 \\
{$\left[\mathrm{Zn}(\mathrm{Nor})_{2}\left(\mathrm{H}_{2} \mathrm{O}\right)_{2}\right] \cdot 2.5 \mathrm{H}_{2} \mathrm{O}$} & $23.51^{\mathrm{a}}$ & $28.90^{\mathrm{b}}$ & $23.33^{\mathrm{b}}$ & $7.71^{\mathrm{a}}$ & 0 \\
$\mathrm{Nystatin}($ positive control) & - & - & - & - & 21.02 \\
\hline
\end{tabular}

0 indicates no activity

Means followed by the same letter indicate no difference in the treatments according to the Scott-Knott test at significance level 0.05

2. The complexation of norfloxacin with $\mathrm{Mn}(\mathrm{II}), \mathrm{Co}(\mathrm{II})$ and $\mathrm{Zn}(\mathrm{II})$ significantly increased activity against the tested gram-negative bacteria;

3. The complexation of norfloxacin with $\mathrm{Cu}(\mathrm{II})$ increases activity against $E$. coli, but did not change activity against $P$. aeruginosa. This result is in disagreement with Ref [16], because the author observed an opposite result (absence of effect against $E$. coli and increased activity against $P$. aeruginosa). This difference may be due to the fact that antibacterial tests did not follow the same methodology or use of different strains of microorganisms.

4. The complexation did not make norfloxacin active against the tested yeast (C. albicans).

The modification of the antibacterial activity of quinolones caused by complexation with metal ions had already been observed in other studies $[2,7,27,30]$. The change of the activity behaves erratically, depending on the metal ion present and the type of microorganism subjected to the tests. An increase in activity is generally attributed to a greater lipophilicity of quinolone complex [2,30], which facilitates the penetration of the antibacterial in the cytoplasm of the microorganism, increasing its efficiency.

\section{Conclusions}

Analytical and thermoanalytical results show that the compounds were synthesized with good purity, and it was thus possible to determine a general minimum formula as $\left[\mathrm{M}(\mathrm{Nor})_{2}\left(\mathrm{H}_{2} \mathrm{O}\right)_{2}\right] \cdot n \mathrm{H}_{2} \mathrm{O}$, where $\mathrm{M}$ represents the bivalent transition metals [Mn(II), $\mathrm{Co}(\mathrm{II}), \mathrm{Ni}(\mathrm{II}), \mathrm{Cu}(\mathrm{II})$ and $\mathrm{Zn}(\mathrm{II})$ ] and $n=3(\mathrm{Ni}), 2.5(\mathrm{Mn} \mathrm{Co}, \mathrm{Zn})$, or $2(\mathrm{Cu})$.

With the thermally analytical results obtained under oxidizing (air) and pyrolysis conditions $\left(\mathrm{N}_{2}\right)$, it was possible to perform a detailed study of the thermal behavior of these complexes and to compare the effect of the atmosphere on the thermal stability and the thermal decomposition profile. In general, the results showed a great influence of the atmosphere used in the processes of thermal decomposition, slight influence on the thermal stability of the copper, manganese and nickel complexes and a negligible influence for the cobalt and zinc complexes. The gases evolved during thermal decomposition of $\mathrm{Ni}$ and $\mathrm{Cu}$ complexes in $\mathrm{N}_{2}$ atmosphere were identified by FTIR. The Ni complex produces $\mathrm{CO}_{2}$ and ethylene in the second step, and $\mathrm{CO}$ in the third and fourth steps. The $\mathrm{Cu}$ compound produces $\mathrm{CO}_{2}$ in the second step, and ethane in the third step of mass loss. In both cases, up to higher temperatures $\mathrm{CO}_{2}$ is continuously evolved, indicating the slow oxidation of carbonized residues in the samples.

The data obtained from diffractograms showed that the complexes with norfloxacin were more crystalline than the norfloxacin in its acid form, following the sequence: HNor $<\mathrm{Cu}<\mathrm{Mn}<\mathrm{Ni}<\mathrm{Co}<\mathrm{Zn}$

The FTIR results suggest that the ligand coordinates to the metal centers by one oxygen atom of the carboxylic group and the oxygen atom from the carbonyl group, forming a six-membered chelate ring.

From the results of antimicrobial activity tests, it was observed that the complexation of norfloxacin modifies the antibacterial activity. The change in activity is erratic and depends on the type of metal ion. The complexes of norfloxacin with $\mathrm{Mn}$ (II), $\mathrm{Co}(\mathrm{II})$ or $\mathrm{Zn}$ (II) were the ones that presented the best results in the tests of antimicrobial activity carried out in this study.

Acknowledgements The authors thank FAPESP (Proc. 2017/149369), CNPq (Proc. 421469/2016-1) and CAPES Foundation (Brazil) for financial support and $\mathrm{PhD}$ Patricia Neves Mendes (UNIFAL-MG) for the aid in the statistical tests. 


\section{References}

1. Mazuel C. Norfloxacin. Anal Profiles Drug Subst. 1991; 557-600. http://linkinghub.elsevier.com/retrieve/pii/S0099542808605407.

2. Shaikh AR, Giridhar R, Yadav MR. Bismuth-norfloxacin complex: synthesis, physicochemical and antimicrobial evaluation. Int J Pharm. 2007;332:24-30.

3. Takahata M, Nishino T. DNA gyrase of Staphylococcus aureus and inhibitory effect of quinolones on its activity. Antimicrob Agents Chemother. 1988;32:1192-5.

4. Garnayak S, Patel S. Oxidative degradation of norfloxacin by a lipophilic oxidant, cetyltrimethylammonium permanganate in water-acetonitrile medium: a kinetic and mechanistic study. J Mol Liq. 2015;209:327-35. https://doi.org/10.1016/j.molliq. 2015.06.003.

5. Zhu Y, Shu G, Yang Y, Dong Q, Zou L. Synthesis and electrochemiluminescence properties of a new ternary terbium complex and its application for the determination of norfloxacin. J Electroanal Chem. 2014;727:113-9. https://doi.org/10.1016/j.jele chem.2014.05.006.

6. Kamble R, Sharma S, Mehta P. Norfloxacin mixed solvency based solid dispersions: An in vitro and in vivo investigation. J Taibah Univ Sci. 2017;11:512-22. http://linkinghub.elsevier. com/retrieve/pii/S1658365517300122.

7. Efthimiadou EK, Psomas G, Sanakis Y, Katsaros N, Karaliota A. Metal complexes with the quinolone antibacterial agent N-propyl-norfloxacin: synthesis, structure and bioactivity. J Inorg Biochem. 2007;101:525-35.

8. Živec P, Perdih F, Turel I, Giester G, Psomas G. Different types of copper complexes with the quinolone antimicrobial drugs ofloxacin and norfloxacin: structure, DNA- and albumin-binding. J Inorg Biochem. 2012;117:35-47.

9. Sadeek SA. Synthesis, thermogravimetric analysis, infrared, electronic and mass spectra of $\mathrm{Mn}(\mathrm{II}), \mathrm{Co}(\mathrm{II})$ and $\mathrm{Fe}(\mathrm{III})$ norfloxacin complexes. J Mol Struct. 2005;753:1-12.

10. Sadeek SA, Refat MS, Hashem HA. Complexation and thermogravimetric investigation on tin(II) and tin(IV) with norfloxacin as antibacterial agent. J Coord Chem. 2006;59:759-75.

11. Ahmadi F, Saberkari M, Abiri R, Motlagh HM, Saberkari H. In vitro evaluation of $\mathrm{Zn}$-Norfloxacin complex as a potent cytotoxic and antibacterial agent, proposed model for DNA binding. Appl Biochem Biotechnol. 2013;170:988-1009. https:// doi.org/10.1007/s12010-013-0255-6.

12. Badea M, Olar R, Silvestro L, Maurer M, Uivarosi V. Synthesis, spectral and thermal studies of the sodium salts of some Ru(III) complexes with quinolone antibiotics. J Therm Anal Calorim. 2017;127:721-9.

13. Mehta JV, Gajera SB, Patel DD, Patel MN. Synthesis, spectral investigation and development of tetrahedral copper(II) complexes as artificial metallonucleases and antimalarial agents. Appl Organomet Chem. 2015;29:357-67. https://doi.org/10.1002/aoc. 3299.

14. Mehta JV, Gajera SB, Patel MN. Antimalarial, antimicrobial, cytotoxic, DNA interaction and SOD like activities of tetrahedral copper(II) complexes. Spectrochim Acta Part A Mol Biomol Spectrosc. 2015;136:1881-92. http://linkinghub.elsevier.com/ retrieve/pii/S138614251401600X.

15. Sarkar K, Sen K. Some drugs in action: metal ions do influence the activity! Int J Pharm Sci Res. 2015;6:1-13.

16. Refat MS. Synthesis and characterization of norfloxacin-transition metal complexes (group 11, IB): spectroscopic, thermal, kinetic measurements and biological activity. Spectrochim Acta Part A Mol Biomol Spectrosc. 2007;68:1393-405.
17. Refat MS, Mohamed GG. Ti(IV), Cr(III), Mn(II), and Ni (II) complexes of the norfloxacin antibiotic drug: spectroscopic and thermal characterizations. J Chem Eng Data. 2010;55:3239-46. https://doi.org/10.1021/je100064h.

18. Wang Y-J, Lin Q-Y, Feng J, Wang N. Diaquabis (norfloxacinato) manganese(II) 2,2'-bipyridine solvate tetrahydrate. Acta Crystallogr Sect E Struct Reports Online. International Union of Crystallography; 2009;65:m806-m806. http://www.ncbi.nlm.nih. gov/pmc/articles/PMC2969423/.

19. Teixeira JA, Nunes WDG, Fernandes RP, do Nascimento ALCS Caires FJ, Ionashiro M. Thermal behavior in oxidative and pyrolysis conditions and characterization of some metal p-aminobenzoate compounds using TG-DTA, EGA and DSCphotovisual system. J Anal Appl Pyrolysis, 2017. http://linkin ghub.elsevier.com/retrieve/pii/S0165237017306526.

20. Suzuki Y, Muraishi K, Ito H. Thermal decomposition of manganese(II) dicarboxylate anhydrides in various atmospheres. Thermochim Acta. 1995;258:231-41.

21. Xu ZP, Zeng HC. Thermal evolution of cobalt hydroxides: a comparative study of their various structural phases. J Mater Chem. 1998;8:2499-506. http://xlink.rsc.org/?DOI=a804767g.

22. Stein SE. "Infrared spectra" by NIST mass spec data center. In: Linstrom PJ, Mallard WG, editors. NIST Chem. WebBook, NIST Stand. Ref. Database Number 69. Gaithersburg, MD: National Institute of Standards and Technology; [cited 2017 Sep 12]. http://webbook.nist.gov/chemistry/.

23. Sahoo S, Chakraborti CK, Mishra SC, Nanda UN, Naik S. FTIR and XRD investigations of some fluoroquinolones. Int J Pharm Pharm Sci. 2011;3:165-70.

24. Huang X-F, Zhang Z-H, Zhang Q-Q, Wang L-Z, He M-Y, Chen $\mathrm{Q}$, et al. Norfloxacin salts with benzenedicarboxylic acids: charge-assisted hydrogen-bonding recognition and solubility regulation. CrystEngComm. 2013;15:6090-100.

25. Gouvea LR, Martins DA, Batista DDGJ, de Maria Nazaré CS, Louro SR, Barbeira PJ, et al. Norfloxacin Zn(II)-based complexes: acid base ionization constant determination, DNA and albumin binding properties and the biological effect against Trypanosoma cruzi. Biometals. 2013;26:813-25.

26. Martins DA, Gouvea LR, Muniz GSV, Louro SRW, Batista D da GJ, Soeiro MDNC, et al. Norfloxacin and N-Donor mixed-ligand Copper(II) complexes: synthesis, albumin interaction, and antiTrypanosoma cruzi activity. Bioinorg Chem Appl 2016;2016: 1-11. http://www.hindawi.com/journals/bca/2016/5027404/.

27. Refat MS, Mohamed GG, De Farias RF, Powell AK, El-Garib MS, El-Korashy SA, et al. Spectroscopic, thermal and kinetic studies of coordination compounds of $\mathrm{Zn}$ (II), Cd(II) and $\mathrm{Hg}$ (II) with norfloxacin. J Therm Anal Calorim. 2010;102:225-32.

28. Deacon G, Phillips RJ. Relationships between the carbon-oxygen stretching frequencies of carboxylato complexes and the type of carboxylate coordination. Coord Chem Rev. 1980 [cited 2014 Apr 28];33:227-50. http://www.sciencedirect.com/science/arti cle/pii/S0010854500804555.

29. Sha J-Q, Li X, Qiu H-B, Zhang Y-H, Yan H. Nickel complexes of the different quinolone antibacterial drugs: synthesis, structure and interaction with DNA. Inorg Chim Acta. 2012;383:178-84. http://linkinghub.elsevier.com/retrieve/pii/S0020169311009108.

30. Huber PC, Reis GP, Amstalden MCK, Lancellotti M, Almeida WP. Synthesis, spectroscopic characterizations and antimicrobial activity of copper and zinc complexes of levofloxacin, ciprofloxacin and 3-carboxy-4-quinolone. Polyhedron. Elsevier Ltd. 2013;57:14-9. 